\title{
D ETHINKING THE STYLISTIC CATEGORIES OF PORTUGUESE 19TH CENTURY SCULPTURE: THE WORK OF ANTÓNIO TEIXEIRA LOPES
}

\author{
MARTA BARBOSA RIBEIRO \\ Universidade de Coimbra \\ martabarbosaribeiro@gmail.com \\ JOANA BRITES \\ Universidade de Coimbra \\ joanabrites@hotmail.com
}

\begin{abstract}
Resumen: El artículo reflexiona sobre las categorías estilísticas de la escultura portuguesa del siglo XIX a partir del análisis de la obra de António Teixeira Lopes, considerado el principal representante del naturalismo escultórico de este país. En primer lugar, se aborda el concepto de naturalismo en la historia del arte portuguesa, ofreciendo una visión crítica sobre su separación en relación con el Romanticismo, a diferencia de la teoría dominante en la historiografía especializada sobre este tema. Al mismo tiempo, demostraremos la dificultad que entraña la aplicación de los conceptos de análisis de la pintura a la escultura cuando se analiza una obra de arte concreta. En segundo lugar, con el contexto artístico portugués como telón de fondo, se estudia la carrera académica y profesional de Teixeira Lopes. Finalmente, a partir del análisis de la obra del escultor y del conocimiento de sus métodos y puntos de vista sobre el arte, se cuestiona el etiquetado de Lopes como naturalista y se defiende la necesidad de una comprensión menos compartimentada del arte del siglo XIX.
\end{abstract}

Palabras clave: Portugal / Escultura / Romanticismo / Naturalismo / António Teixeira Lopes.

Abstract: This paper aims to rethink 19th century Portuguese sculpture's stylistic categories from the analysis of the work of António Teixeira Lopes, who is considered the major representative of naturalism in this country. First, the concept of naturalism in Portuguese art history is examined, with a critical characterization of its separation from romanticism (contrasting with mainstream literature) and demonstrating that its emergence from painting research and its adoption in sculpture is inoperative when observing a concrete art work. Secondly, with the Portuguese art reality as a backdrop, Teixeira Lopes' academic and professional life is contextualised. Finally, based on the analysis of the sculptor's work and the knowledge of his methods and views on art, the labelling of Lopes as a naturalist is questioned and the necessity for a less compartmentalized understanding of 19th century art is stressed.

Key words: Portugal / Sculpture / Romanticism / Naturalism / António Teixeira Lopes.

\section{Naturalism category in Portuguese art history: travelling from painting to sculpture}

Defining romanticism is a challenge for international art historiography. The broadness, multifacted character and chronological diversity of the reality it encompasses, a large cultural movement rising in the 19th century, is systematically stressed. Nevertheless, some relatively pacific consensus among researchers is detected regarding the historical spurring of this phenomenon, its geographical epicenters and the need to understand it as far more complex than a simple opposition to classical references. ${ }^{1}$ With special emphasis in

\footnotetext{
* Fecha de recepción: 15 de abril de 2017 / Fecha de aceptación: 22 de septiembre de 2017

1 BARKER, Emma (ed.). Art \& Visual Culture, 1600-1850. United Kingdom: The Open University, 2012; BERGER, Stefan. A Companion to nineteenth-Century Europe, 1789-1914. Oxford: Blackwell Publishing, 2009; BERLIN, Isaiah. The roots of Romanticism. London: Pimlico, 2000; CRANSTON, Maurice. The Romantic Movement. Oxford: Blackwell Publishers, 1994; DAY, Aidan. Romanticism. Oxon: Routledge, 2012; EISENMAN, F. Stephen. Nineteenth century art, a critical history. London: Thames and Hudson Ltd, 1998; NOVOTNY, Fritz. Painting and Sculpture in Europe, 1780-1880. United Kingdom: The Pelican History of Art, 1960; TAYLOR, Joshua C. Nineteenth-Century Theories of Art. California: University of California Press, 1897;
} 
France, England and Germany, romanticism reflects a reaction to capitalism and urban development and the resulting shifts in social structure. It lingers on the melancholic and nostalgic anxiety concerning a sense of self and sociability which are perceived as lost. The reaction and critique to the modernization process, regarded as being responsible for these changes, unfolds in various artistic fields and stylistic languages. The reunion of contradicting adjectives used to characterize this multilayered movement demonstrates its non linear nature: "revolutionary and counterrevolutionary, individualistic and communitarian, cosmopolitan and nationalistic, realistic and fantastic, retrograde and utopian, rebellious and melancholic, democratic and aristocratic, activist and contemplative, republican and monarchist, red and white, mystical and sensual". ${ }^{2}$ The difficulty to clearly establish a definition of romanticism results in the repeated recovery of Charles Baudelaire's 1846 formulation, which underlines a way of being instead of a thematic and stylistic delimitation: "romanticism is precisely located neither in the choice of subject nor in exact truth, but in the mode of feeling". ${ }^{3}$

In general, naturalism is considered a strand of romanticism in several art forms, although in mainstream literature on sculpture, this distinction is not often made. Denominated as "landscape instinct" ${ }^{4}$ by John Ruskin ${ }^{5}$ and mainly applied in painting, it constitutes an attempt of capturing what was perceived as a truthful and pure nature, untouched by modern society, thus depicted in the same nonartificial way: in direct open air, centred on working the same subject throughout different light and colour variations.

However, in Portuguese art history, romanticism and naturalism are clearly seen as independent and differentiated in terms of chronologies, themes, techniques and colour. In painting, the historiographical distinction between romanticism and naturalism is operated by mobilizing several factors. To begin with, a thematic variation is verified: while romanticism, moved by a "symbolic essentiality", 6 portrays the picturesque and the nostalgic past, ${ }^{7}$ naturalism focuses on the present $^{8}$ and privileges a visual inventory of concrete sites and places, ${ }^{9}$ influenced by the ethnographic spirit of the time. Secondly, a different chronology is pointed out, locating romantics in the first half of the 19th century and naturalists after 1880 . With regards to technique, the differences rest on the way light is captured and the colour palette is handled. Romantics, even when depicting natural light, return to the studio and apply bitumen which darkens the canvas. ${ }^{10}$ Naturalists, on the other hand, in a so-called "anti-academic attitude", ${ }^{11}$ painted in plein air, in search of truthfulness. ${ }^{12}$ Dismissing the sketch, the outcome was brighter and lighter, less detailed and less accu-

VAUGHAN, William. Romanticism and Art. London: Thames \& Hudson Ltd, 2003; WU, Ducan. A Companion to Romanticism. Oxford: Blackwell Publishing, 1999; HARRISON, Charles; WOOD, Paul; GAIGER, Jason. Art in Theory, 1815-1900, An Anthology of Changing Ideas. Oxford: Blackwell Publishing, 1998; FEBER, Michael. Romanticism, A very short introduction. Oxford: University Press, 2010.

2 LOWY, Michael; SAYRE, Robert. Romanticism and Against the Tide of Modernity. London: Duke University Press, 2001, p. 1.

3 BAUDELAIRE, Charles. "What is romanticism?". En: TAYLOR, Joshua C., 1987 (nota 1), p. 222.

${ }^{4}$ LUKACHER, Brian. "Nature historicized: Constable, Turner and romantic landscape painting". En: EISENMAN, F. Stephen, 1998 (nota 1), p. 155.

5 LUKACHER, Brian. "Nature historicized: Constable, Turner and romantic landscape painting". En: EISENMAN, F. Stephen, 1998 (nota 1), pp. 115-143; VAUGHAN, William, 2003 (nota 1) pp. 197-207. NOVOTNY, Fritz, 1960 (nota 1), p. 110.

${ }^{6}$ PORFÍRIO, José Luís. "Da expressão romântica à estética naturalista: pintura e escultura". En: RODRIGUES, Dalila (coord.). Arte Portuguesa da Pré-História ao Século XX. Lisboa: Fubu Editores, 2009, p. 35. Translation by the authors.

7 FRANÇA, José-Augusto. A arte em Portugal no século XIX. Vol. I, vol. II. Lisboa: Livraria Bertrand, 1966, p. 254.

8 SILVA, Raquel Henriques da. "O naturalismo e o portuguesismo em pintura". En: FALCÃO, Isabel; PROENÇA, José António (coord.). João Vaz, 1859-1931, Um pintor do naturalismo. Lisboa: Casa-Museu Anastácio Gonçalves, 2005, p. 16.

9 SILVA, Raquel Henriques da. "Silva Porto e a pintura naturalista". En: LAPA, Pedro; SILVEIRA, Maria de Aires (coord.). A Arte Portuguesa do Século XIX (1859-1910). Lisboa: Museu Nacional de Arte Contemporânea - Museu do Chiado e Leya, 2010, p. 51.

10 PORFíRIO, José Luís. "Da expressão romântica à estética naturalista: pintura e escultura". En: RODRIGUES, Dalila (coord.), 2009 (nota 6), p. 28.

11 FRANÇA, José-Augusto, 1966, vol. II (nota 7), pp. 23, 27, 45.

12 FRANÇA, José-Augusto, 1966, vol. II (nota 7), pp. 24, 45; MÂNTUA, Ana Anjos; SILVEIRA, Maria de Aires (ed.). Fórmulas Naturalistas da Arte Moderna nas coleções da Casa-Museu Dr. Anastácio Gonçalves e no Museu Nacional de Arte Contemporânea-Museu do Chiado. Lisboa: Direção Geral do Património Cultural, 2016, pp. 28, 29; SILVA, Raquel Henriques da. "O naturalismo e o portuguesismo em pintura". En: FALCÃO, Isabel; PROENÇA, José António (coord.), 2005 (nota 8), pp. 17, 25. 
rate $^{13}$. Light itself becomes the subject of the art work, thus progressively announcing the abandonment of motive representation as the artistic creation's ultimate goal, which will later thrive in modern art. Despite the fact that historiography separates them in two different movements, it is recognized that they share an interest for themes related to nature, daily activities in rural life, landscape, animals and portraits, which aim to capture more the emotional features of the person being depicted, than his/her social status.

In Portuguese historiography on the $19^{\text {th }}$ century sculpture, the strong and undoubtful contrast established between romanticism and naturalism does not correspond to a similarly solid conceptual framing. Therefore, when facing a specific art work, these categorizations, which furthermore interact with an extra one -that of classicismprove to be inoperative. As an example, one might quote the stylistic analysis of what is considered the master piece of each category. "Camões" (1860), figure which at the time embodied the national identity and pride, was the first non-monarchic statue to be erected in Portugal using citizens' financial contribution. ${ }^{14}$ The statue was designed by Vítor de Bastos (18291894), acclaimed to be the most romantic sculptor of the time. ${ }^{15}$ It is argued that "Camões" [image no. 1] has an "academic composition" which "invents costumes and postures of the Renaissance, shaping bodies and expressions with a naturalistic refinement". ${ }^{16}$

On the other hand, "Viúva" [Widow], molded in 1889 (image no. 2) by the artist known as the most representative of Portuguese naturalism, ${ }^{17}$ António Teixeira Lopes (1866-1942), is characterized as "a sentimental and expressive piece [of] a downhearted body [...] underlining her psychological situation", ${ }^{18}$ although in general it remains "faithful to

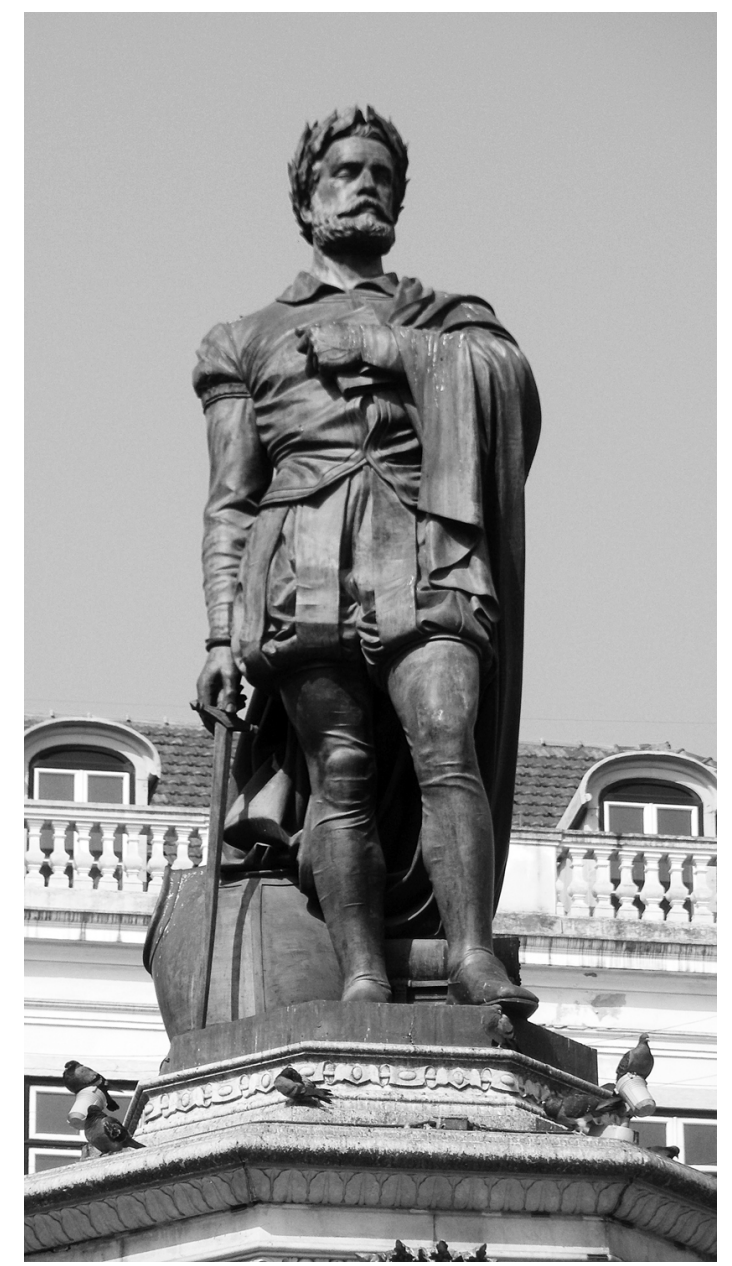

Image 1. Vítor Bastos, "Monument to Camóes", 1860, Lisbon, Photographed by the authors.

the modulation and thematic classical heritage". ${ }^{19}$ The quest for national heroes in romanticism is perceived as absent in naturalism, which is described as being more concerned with common human beings facing common situations. ${ }^{20}$

13 SILVA, Raquel Henriques da. "Romantismo e pré-naturalismo". En: PEREIRA, Paulo (dir.). História da Arte Portuguesa. Lisboa: Círculo de Leitores, 2008, pp. 160, 161.

14 FRANÇA, José-Augusto, 1966, vol. I (nota 7), p. 333.

15 SILVA, Raquel Henriques da. "Romantismo e pré-naturalismo". En; PEREIRA, Paulo (dir.), 2008 (nota 13), p. 159. On this subject, see, also, PORFÍRIO, José Luís. "Da expressão romântica à estética naturalista: pintura e escultura". En: RODRIGUES, Dalila (coord.), 2009 (nota 6), p. 35; FRANÇA, José-Augusto, 1966, vol. I (nota 7), p. 288.

16 SILVA, Raquel Henriques da. "Romantismo e pré-naturalismo". En: PEREIRA, Paulo (dir.), 2008 (nota 13), p. 159; FRANÇA, José-Augusto, 1966, vol. Il (nota 7), p. 220. Translation by the authors.

17 SILVA, Raquel Henriques da. "Romantismo e pré-naturalismo". En: PEREIRA, Paulo (dir.), 2008 (nota 13), p. 177.

18 PORFÍRIO, José Luís. "Da expressão romântica à estética naturalista: pintura e escultura". En: RODRIGUES, Dalila (coord.), 2009 (nota 6), p. 71. Translation by the authors.

19 SILVA, Raquel Henriques da. "Romantismo e pré-naturalismo". En: PEREIRA, Paulo (dir.), 2008 (nota 13), p. 177. Translation by the authors.

20 FRANÇA, José-Augusto, 1966, vol. II (nota 7), p. 45; SILVA, Raquel Henriques da. "O naturalismo e o portuguesismo em pintura". En: FALCÃO, Isabel; PROENÇA, José António (coord.), 2005 (nota 8), p. 16. 


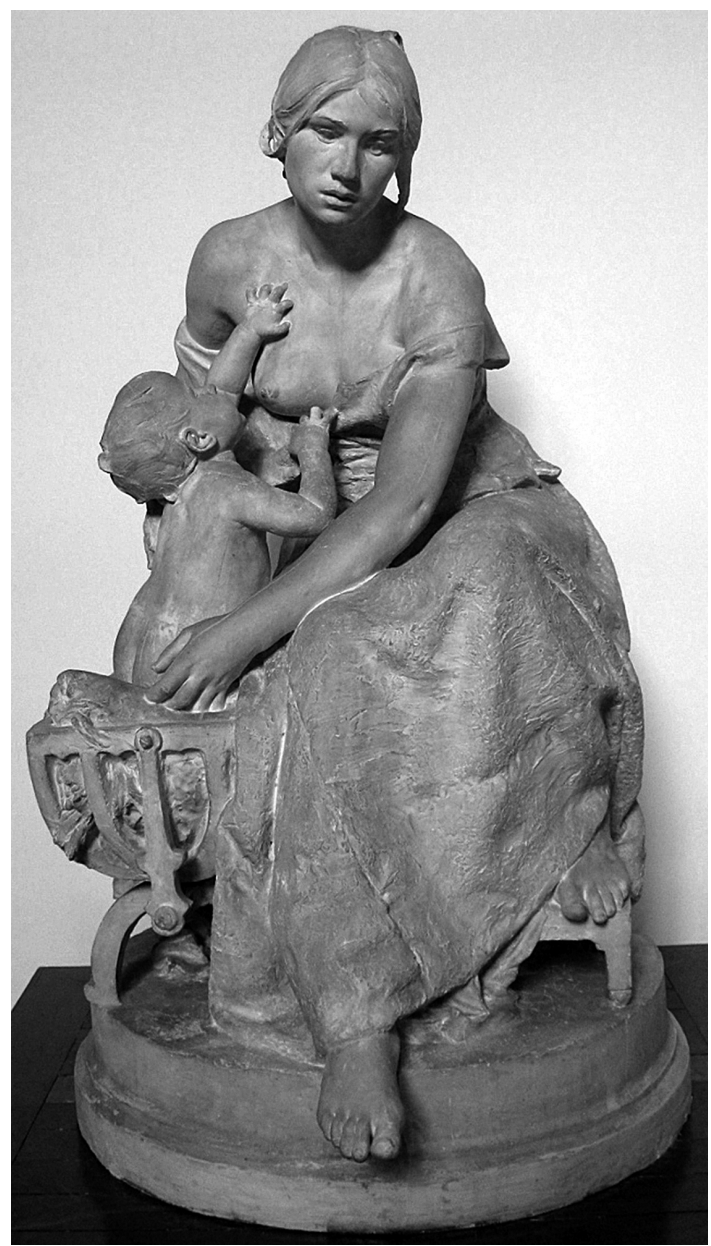

Image 2. António Teixeira Lopes, "Viúva" (Widow), 1889, plaster, $156 \times 94 \times 105 \mathrm{~cm}$, Casa-Museu Teixeira Lopes (House Museum of Teixeira Lopes), Photographed by the authors.

The fragility of the argumentation exposed above is, in our view, explained by the fact that Portuguese historiography on the $19^{\text {th }}$ century sculpture was produced by researchers of painting of the same time frame, who tend to impose to the first artistic field the evolution detected in the second. This primacy of painting, and the consensual conviction that it acted as the main renovator of art in this period, comes from the pioneering role and recognized impact of the two painters, António Silva Porto (1850-1893) and João Marques de Oliveira (1853-1927), who first benefited from a State allowance to upgrade their education in Paris between 1873 and 1879, city that acted as the booster of artistic actualization. This narrative contributed to convert sculpture, as José
Fernandes Pereira emphasises regarding its lack of theorization compared to that of painting, into the "poor relative, perhaps because its production rhythm does not fit easily into the labels that usually codify the 19th century". ${ }^{21}$

The adoption of stylistic categories that were born in a specific artistic field by another brings risks that should be pondered. In fact, sculpture comprehends different techniques, materials, creative methods and stages and, thus, a diverse evolution pace. A sculpture completed in the $19^{\text {th }}$ century encompasses various phases: it starts with the drawing, followed by a clay draft in small scale, for it to fit in the oven. The plaster, which dries faster and does not need to be baked, can then be used to amplify the initial sketch. After these two steps, which rest on an additive procedure, the subtractive stage finally begins, when the work is carved from hard materials (such as marble, wood or stone). In alternative, bronze can be forged from the initial clay draft (allowing, if desired, the "painterly painted" texture of the sculpture). As a result, the sculpture of this period hardly translates the capture of a single moment, the spontaneity or rapid execution, which is typical of naturalist strokes. The eventual non-finito aspect of a sculpture, which can erroneously be interpreted as naturalism, often intends to stress the content rather than diminishing its centrality and does not necessarily correspond to a faster creative process. Auguste Rodin's Monument to Balzac (1897), for instance, took seven years to be completed, went through several sketches, different and separated body mould studies and intended to capture the personality of the writer rather than its physical appearance. ${ }^{22}$

In historiography of the $19^{\text {th }}$ century Portuguese sculpture, as one can verify in several art history fields and chronologies, a global interpretation was constructed and widely disseminated before any monographic studies on the respective artists. Therefore, upcoming research focused on a particular sculptor may question the initial narrative. Analysing the work of António Teixeira Lopes, one of the most renowned and influent Portuguese sculptors of this century, constitutes therefore an opportunity to test and review the mainstream understanding of Portuguese sculpture in this period, since his work has not been extensively studied and even when it was partially

21 PEREIRA, José Fernandes. "Teoria da escultura portuguesa: 1874 - ao fim do século". Arte teoria, 2000, n 9, p. 288.

22 DUMEZ, Hervé. "Rodin, le Balzac et l'étude de cas". Le Libellio d' Aegis, 2007, vol. 3, pp. 35-39. 
approached, it was the target of a more evaluative reading, rather than an explanatory one. ${ }^{23}$

\section{The Portuguese 19th century in arts and António Teixeira Lopes' education and professional life}

The beginning of the Portuguese $19^{\text {th }}$ century was characterized by political, social and economic tensions that determined the crisis of the Ancien Régime. Napoleonic invasions (1807-1811), the transfer of the Portuguese royal court to Brazil (1808-1821), the British rule under General William Beresford and the Liberal Revolution of 1820 had considerable impact on the artistic evolution of the country. Consequently, the arts were somewhat kept in abeyance, since commissions stagnated and the public remained faithful to earlier stylistic taste.

After the liberal victory in the Portuguese civil war of 1832-1834, the country was finally able to rethink education, among other aspects, which was perceived as instrumental for the development of the country and the supply of State ranks. The foundation of two Fine Arts Academies in 1836, in Oporto and Lisbon, included in that effort, were aimed at recovering the artistic delay. However, this impulse for renovation was weakened because teaching staff selection was made from the artists who worked for the royal court before leaving for Brazil, such as Constantino José dos Reis (1778-1865) who was a disciple of Joaquim Machado de Castro (1731-1822), author of the equestrian statue of King Jose I, in Lisbon (1775). Therefore, the heritage of the end of the $18^{\text {th }}$ century in sculpture was prolonged. Trying to overcome this fragility, the Government instituted allowances, open to competition, which supported long-term stays mainly in Paris. In alternative, artists found their own personal or familiar means to experience the same city. As an example, one can refer the academic path of António Soares dos Reis (1847-1889), author of one of the most known sculptures of the $19^{\text {th }}$ century ("Desterrado" [Exiled], 1872), who was in Paris with a State scholarship in the late 1860's and completed his education with an additional year in Rome ${ }^{24}$. On the other hand, António Teixeira Lopes benefited from his family financial support in order to leave for Paris in 1885.

Born in Vila Nova de Gaia in 1866, António Teixeira Lopes presents what can be described as a traditional artistic education at the time. Having been initiated in the sculpting art in his father's workshop in 1873, he entered in the Academy of Fine Arts in Oporto in 1882. When in 1885 he lost the competition for a State allowance for furthering his instruction in Paris, he left that year by himself with the contribution of his parents. Throughout this journey, for which Teixeira Lopes used the train and not the boat, unlike Soares dos Reis did some years before, he visited theatres and museums, which enlarged his knowledge of world art. His visit to Prado Museum was especially unforgettable for him. As he describes in his Memórias [Memories]:25 it was in Prado "this admirable museum where I was able to feel, vibrate with excitement, my whole temperament of artist for the first time. I spent hours there marvelling before the canvases of Velasquez, Murillo, Ribera, Goya". ${ }^{26}$ In sculpture, French museums were however more significant to him and acted as a crucial complement to his artistic education and actualization. ${ }^{27}$ François Rude for instance, considered in his view a "genius of statuary", ${ }^{28}$ will influence his work. These years, spent not only in Paris (where he saw the Universal Exhibition of 1889, later accounted in detail in his Memórias ${ }^{29}$ ) but also with short visits to other cities, such as Berlin or Luxembourg, gave him the possibility to get acquainted with artists as Auguste Rodin (1840-1917) or Frédéric Auguste Bartholdi (1834-1904)..$^{30}$ This also provided a first-hand experience that allowed him to position himself regarding evolution of sculpture in general, a theme that occupies several pages in his writing.

23 ABREU, José Guilherme Pinto. A escultura no espaço público do Porto no século XX: inventário, história e perspectivas de interpretação. Tesis (Magister en Historia del Arte). Porto, Portugal, Universidad do Porto, Faculdade de Letras, 1996250 p. And also, TEIXEIRA, José Manuel da Silva. A mulher na escultura de António Teixeira Lopes. Tesis (Magister en Teorias del Arte). Lisboa, Portugal, Universidad de Lisboa, Faculdade de Bellas Artes, 2001, 161 p.

24 FRANÇA, José-Augusto, 1966, vol. I (nota 7), p. 333.

25 LOPES, António Teixeira. Ao correr da pena. Memórias de uma vida... Gaia: Câmara Municipal de Vila Nova de Gaia, 1968.

26 LOPES, António Teixeira, 1968 (nota 25), p. 11. Translation by the authors.

27 LOPES, António Teixeira, 1968 (nota 25), pp. 13-14, 65-66.

28 LOPES, António Teixeira, 1968 (nota 25), p. 50. Translation by the authors.

29 LOPES, António Teixeira, 1968 (nota 25), pp. 45, 66-67.

30 LOPES, António Teixeira, 1968 (nota 25), pp. 198-200, 254. 
Despite his travelling and stays overseas, Teixeira Lopes maintained a close relationship and interaction with the Portuguese artistic scenario, within the framework of a devised strategy for his affirmation. This explains how he could organize a solo exhibition, rare at the time, in 1890 in Oporto, and received a commissioned work four years later from the last Portuguese Queen, Maria Amélia de Bourbon-Orléans ("Rainha Santa", inaugurated in 1896). ${ }^{31}$ At this time the main part of his inhouse atelier, located in Vila Nova de Gaia, was already constructed. However, he did not abandon Paris for good, since he kept his first rented atelier there until the beginning of the $20^{\text {th }}$ century. He was by then a sculptor with some international expression, as certified by the sculpting work of Candelária Church's doors in Rio de Janeiro (1898) and the participation in the 1900 Universal Exhibition in Paris. ${ }^{32}$ In 1901, he was appointed by King Carlos I as the successor of Soares dos Reis in the course of Sculpture at the Academy of Fine Arts of Oporto. ${ }^{33}$

His house in Gaia, designed around a major atelier by his brother under his supervision, was constructed from the last decade of the $19^{\text {th }}$ century to the beginning of the $20^{\text {th }}$ century. It acted as dynamic social and artistic centre, gathering writers, musicians, actors and other visual artists in frequent soirées. His atelier was began to have a parallel exhibition space for his one work and later, after the completion of his workshop in the backyard of the house, was completely devoted to show his sculpture. ${ }^{34}$

In 1933 he donated his house, belongings and a major part of his sculpture works, thoroughly selected and listed in a detailed inventory, to the municipality of Vila Nova de Gaia in exchange for a lifetime monthly accrual, thus giving origin to the "House Museum Teixeira Lopes", of which he was the first Director (1933-1942). ${ }^{35}$

The transference of his assets to this municipality was the result of the combination of different reasons and motivations: the necessity to stabilize his financial situation; the need to prevent the dispersion of his work; the influence of a heritage conscience which emerges at the end of the century, and the will and commitment to ensure his own place in Portuguese art history. From the 285 sculptures donated to Vila de Gaia Municipality, ${ }^{36}$ our examination comprehended the ones in permanent exhibition (149), since the museum storage is not accessible to visitants or researchers. The final part of this paper rests in the revision of the stylistic framing of his work, based on our previous analysis of these 149 pieces.

\section{Rethinking António Teixeira Lopes: his methods, thinking and stylist classification}

According to António Teixeira Lopes, ${ }^{37}$ the investment in proper instruction that provides the tools for the mastery of the technique, of the correction of proportions and form, although essential, was not enough for a sculptor. These tools only helped to better express the artist's feelings. Without them remains only the canon which, despite producing sculptures that are credible to an audience, does not move. In his opinion the artist is a situated being. Therefore, the creative process takes into account the temperament, education and milieu. From a very romantic perspective, "a work that thrills", ${ }^{38}$ will come from the soul, not from the brain. For its correct expression, along with natural talent, only constant rigor and effort could guarantee the quality of the work. A true work of art is born, in Teixeira Lopes' opinion, by the pursuit of perfection and beauty. These are

31 LOPES, António Teixeira, 1968 (nota 25), pp. 79-80, 161-171.

32 LOPES, António Teixeira, 1968 (nota 25), pp. 194, 202, 243, 272, 284.

33 LOPES, António Teixeira, 1968 (nota 25), pp. 293, 303.

34 LOPES, António Teixeira, 1968 (nota 25), pp. 170, 330. On the subject of housing in $19^{\text {th }}$ century, see, among others, ELEB, Monique; DEBARRE, Anne. L'invention de l'habitation moderne, Paris 1880-1914, Suisse: Edition Hanzan et Archives d'Architecture Moderne, 1995, p. 86.

35 Escritura de doação dos prédios onde nasceu e anexos onde existiu os seus atelieres, oficinas e dependências destinado ao comércio da sua profissão de escultor, 1933, Municipal Archive of Vila Nova de Gaia, Identifier: 2278, partial code: Lv. 16, fl. 87-93v, file number: F/04 /II/1 - Pt. 3.

${ }^{36}$ Inventário da Escritura de doação dos prédios onde nasceu e anexos onde existiu os seus atelieres, oficinas e dependências destinado ao comércio da sua profissão de escultor, Casa-Museu Teixeira Lopes (House Museum of Teixeira Lopes).

37 RIBEIRO, Marta Barbosa. António Teixeira Lopes: a construção do artista e a interpretação da obra.

Tesis (Magister en Historia del Arte, Património y Turismo Cultural). Coimbra, Portugal, Universidad de Coimbra, Faculdade de Letras, 2016, $136 \mathrm{p}$.

38 LOPES, António Teixeira, 1968 (nota 25), pp. 164, 664. Translation by the authors. 


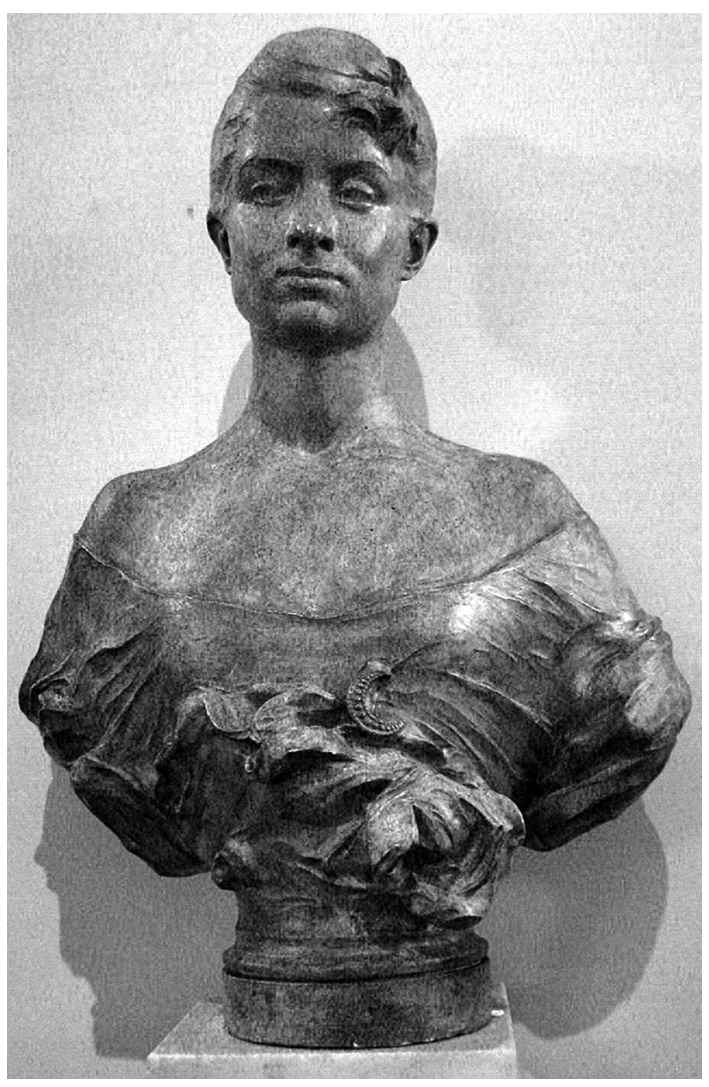

Image 3. António Teixeira Lopes, "Madame X”, 1893, patinated plaster, $79 \times 57$ × $35 \mathrm{~cm}$, Casa-Museu Teixeira Lopes (House Museum of Teixeira Lopes), Photographed by the authors.

found in simplicity of expression, in delicacy, in softness, articulated simultaneously with strength and consistency. The psychological density of a work is progressively achieved by balancing the degree of detail, in order to emphasize and distinguish what is essential and secondary. ${ }^{39}$ This method was exploited in bust of "Madame X" (1893) (image no. 3), work refused by the portrayed woman who did not recognize herself and did not like the excessive neckline ${ }^{40}$. He simplified the outer line which enhanced the expressiveness of the central nucleus: the face and the intensity of the eyes, thus leading the viewer to focus on the essential.

In "Viúva" [Widow], from 1889, the transition between the more detailed part of the work -the baby cradle- and the more faded texture of the female figure underlines the emotional drama of this woman, physically and physiologically distant, withdrawn and intangible. The widow's prominent foot down below, which interrupts the circu-

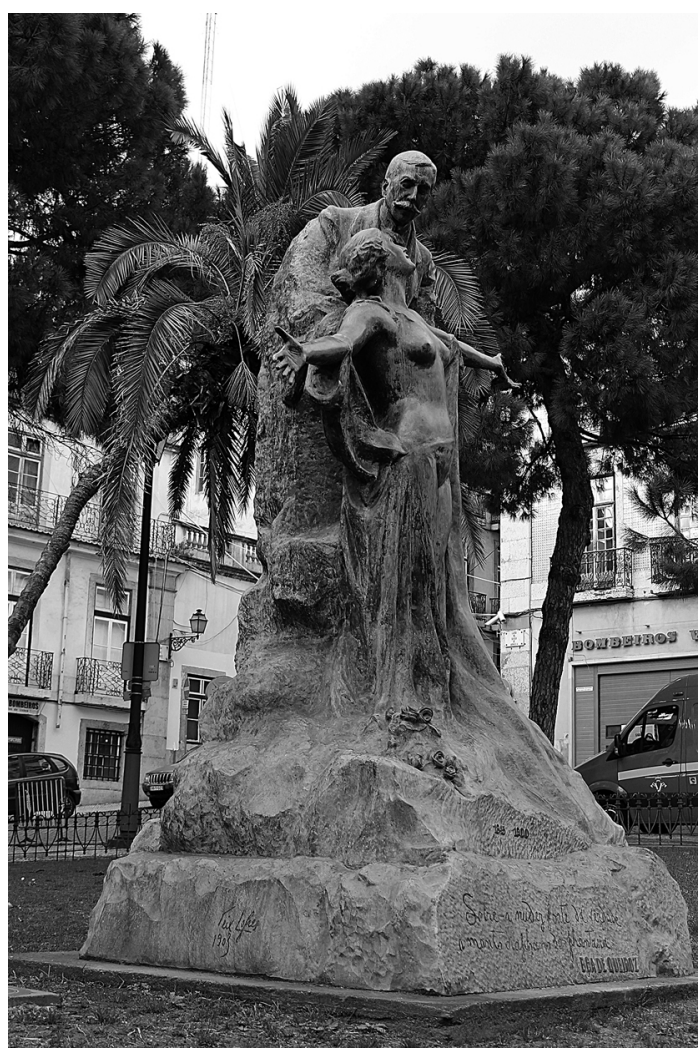

Image 4. António Teixeira Lopes, "Monument to Eça de Queiróz”, 1903, bronze, Lisbon, Photographed by the authors.

lar basis, an allegory of the circle of life, establishes the axis of the composition, dividing the work into the two aforementioned sections. Connecting them, the woman's arm, which evokes the formula fixed by Caravaggio in the Entombment of Christ, alludes to the loss of life and rests on her knee, which in turn is vertically aligned with the foot.

The same dichotomy between an accurate shape and a more simplified modelling is key to understand the monument to Eça de Queiróz (1903) (image no. 4), which illustrates a phrase that follows the main title of one of the writer's most famous books, The Relic (1887): "Over the sturdy nakedness of truth the diaphanous cloak of fantasy". The thematic dualism between truth and fantasy is reflected in the formal dualism with which the sculptor played with the viewer's perception and shaped each one of the figures. Seen from the front, the bodies seem to be separated: the writer with detailed and creased features and the

39 LOPES, António Teixeira, 1968 (nota 25), pp. 105, 159, 189, 603, 655.

40 LOPES, António Teixeira, 1968 (nota 25), p. 135. 
woman with a silky texture. However, seen from the side, it becomes clear that they sprout from the same stone, as if coming from a single reality.

The different depth of detail and finishing aspect in the same work was crucial to Teixeira Lopes to capture the different levels of drama in the depicted figure and situation. For this reason, fellow artists who produced a uniform sculpture, even if excelling in technique by strictly following the canon, were criticized under his eyes. In this sense, German sculpture was, in António Teixeira Lopes' view, far from French delicacy and grace. In the case of Reinhold Begas (1831-1911), despite having an undeniable technique, the work resulted, in his opinion, in a cold and monotonous classicism. ${ }^{41}$ Regarding his teachers, despite his admiration, the same lack of emotion was detected. He condemns the excessive correction of PierreJules Cavelier's (1814-1894) lines of composition, resulting in a wintry and conventional work. In relation to his master Louis Ernest Barrias (18411905), he denounces classic conventions had not been overcome, which "prevented him from translating the truth more frankly" ${ }^{42}$ Finally, he classifies António Soares dos Reis as an artist capable of excellence in technique but hostage to his excessive fidelity to his classical training and nature. ${ }^{43}$

He regards nature as the source of inspiration. Nevertheless, he states that it should not be copied but translated through art. Furthermore, he romantically insists that models should never stand in a static pose; on the contrary they must circulate freely on the atelier. In fact, only in an intimate scenario and with a natural behaviour, the model's soul could be captured. ${ }^{44}$ The bust of Teófilo Braga (1916) was produced with daily sessions of about three hours each, during which the politician would walk around talking, thus, "undergoing successive transformations that the artist observes penetrating deep into the sujet by capturing his essence: the portrait of the soul". ${ }^{45}$

António Teixeira Lopes also argued that, after a close observation of the motive, sometimes it

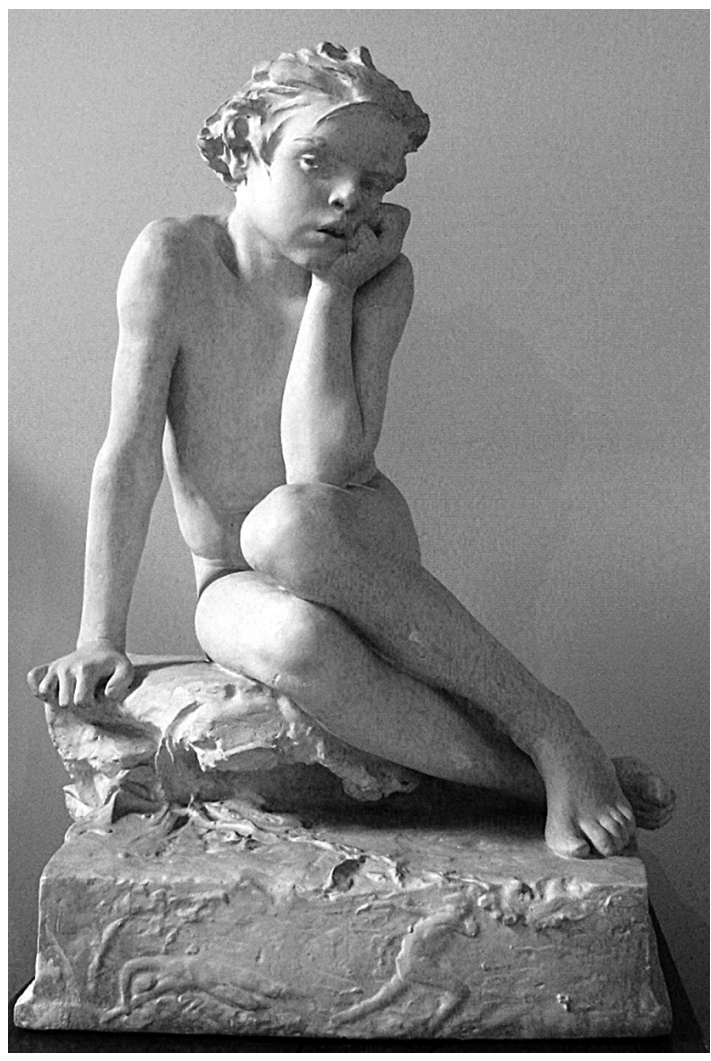

Image 5. António Teixeira Lopes, "Cain”, 1890, plaster, 103 x 74 x $60 \mathrm{~cm}$, Casa-Museu Teixeira Lopes (House Museum of Teixeira Lopes), Photographed by the authors.

would be necessary to turn his back on the model and even on classical canon guidelines, in order for inspiration to emerge. ${ }^{46}$ In Memórias he states that the quality of a work does not come, for the most part, from the absolute reality of things but "from its spirit, from its essence". ${ }^{47}$ This very same practice was discussed with Auguste Rodin in the atelier of the latter, and they both agreed that copying must be avoided and, thus, the artist should restart the work multiple times and never discard the first studies. ${ }^{48}$ This method, in Teixeira Lopes' experience, was difficult to conciliate with the pressure to deliver a commissioned work, since he stated that months of labour and "meditation" were absolutely required. ${ }^{49}$

\footnotetext{
41 LOPES, António Teixeira, 1968 (nota 25), p. 599.

42 LOPES, António Teixeira, 1968 (nota 25), p. 111. Translation by the authors.

43 LOPES, António Teixeira, 1968 (nota 25), pp. 163, 164.

44 LOPES, António Teixeira, 1968 (nota 25), pp. 589- 590.

${ }^{45}$ LOPES, António Teixeira, 1968 (nota 25), p. 590. Translation by the authors.

${ }^{46}$ LOPES, António Teixeira, 1968 (nota 25), pp. 138, 199, 590.

${ }^{47}$ LOPES, António Teixeira, 1968 (nota 25), p. 31. Translation by the authors.

${ }^{48}$ LOPES, António Teixeira, 1968 (nota 25), pp. 199-200.

${ }^{49}$ LOPES, António Teixeira, 1968 (nota 25), p. 523.
} 
The intentional diminishing of sharpness and definition, which Portuguese art history uses to characterize naturalism in sculpture, taking this aspect from a similar effect verified in painting, was indeed a mechanism to enter the interior world of the model and not the translation of a spontaneous and superficial impression of the motive. This, in Teixeira Lopes' opinion, should be avoided, to escape what he thought to be an issue with Italian and French painters, who "only observe the surface of things without penetrating into its core". ${ }^{50}$ For him, spontaneity was only achieved by hours spent with the model and simplicity required years of training. Furthermore, often his work implies the combination of different models, thus his composition is thoughtfully and complexly composed. Two works illustrate this type of composition with particular clarity. In the study of the sculpture of the "Rainha Santa" [Holy Queen Isabel] (1896) Teixeira Lopes used four models: one French and one Italian woman for the nude; a Portuguese woman for the design of the garments and, finally, for the execution of the head, a "most distinguished lady... of Aragon", 51 the Queen's place of birth. Similarly, in the funerary monument dedicated to the historian Joaquim Oliveira Martins (1898), the female figure, an allegory of History, was modelled after a woman body, although for her hands, since the sculptor was not able to find "proper" real hands for them to be drawn up from, he mixed the hands of his pianist friend with those of a woman..$^{52}$

If regarding his technique, the naturalist labelling of António Teixeira Lopes is, as has been argued, very problematic, in terms of thematic choices, his sculpture peacefully remains within romanticism preferences. This can be easily demonstrated by two works. Cain (image no. 5), from 1888, is a work of biblical inspiration, in which a naked boy, sitting on a stone and absorbed in his thoughts, stares which a Machiavellian look. In this work, the child's anatomically perfect body, in plain white marble, contrasts the aggressiveness of his eyes fixed in his intention, with his hands closed and body twisted. The compositional line of the arm and leg lead the viewer to the basis of the work, where the story of Cain is carved in a low detailed relief.

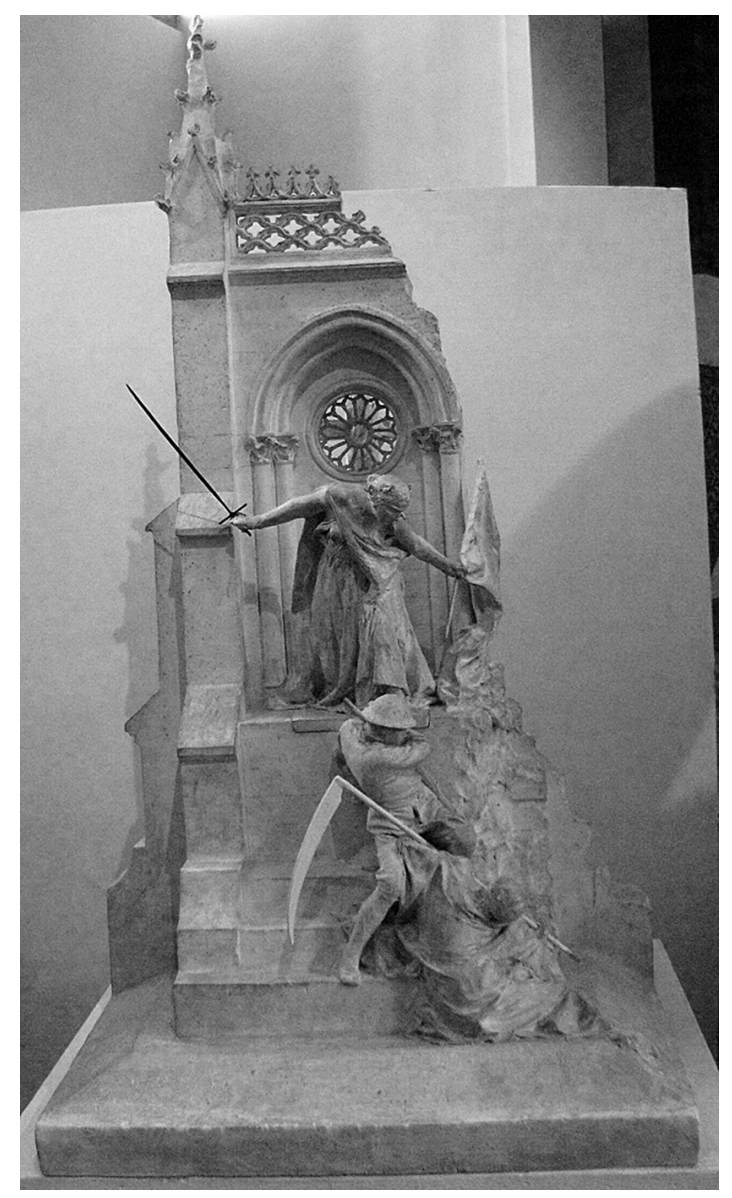

Image 6. António Teixeira Lopes, Model of the monument dedicated to honour the participation of the Portuguese in the First World War, 1925, plaster, Casa-Museu Teixeira Lopes (House Museum of Teixeira Lopes), $129 \times 68 \times 84 \mathrm{~cm}$, Photographed by the authors.

In its turn, in the monument of La Couture (1925), which was intended to honour the participation of the Portuguese in the First World War (image no. 6), Teixeira Lopes uses the most known romanticism tropes. The scenario of this piece is a ruin which alludes to Monastery of Batalha, a medieval architectonical landmark which became the symbol of national independence and identity. The artist sustained that "we all [Portuguese] should go once a year on a pilgrimage to this marvellous temple, and kneel and fortify our spirits, renew our souls, ask for inspiration and courage to continue the work of regeneration". ${ }^{53}$ Three figures stand in the front: an allegory of

\footnotetext{
50 LOPES, António Teixeira, 1968 (nota 25), p. 657. Translation by the authors.

${ }^{51}$ LOPES, António Teixeira, 1968 (nota 25), pp. 165, 169. Translation by the authors.

52 LOPES, António Teixeira, 1968 (nota 25), pp. 194-198, 201.

53 LOPES, António Teixeira, 1968 (nota 25), p. 237. Translation by the authors.
} 
Homeland at the top (a woman holding a sword); an allegory of Death in the bottom (a skeleton lying on the floor) and a soldier standing with a rifle in his hand, preventing the latter to reach the first. Behind this group there is a depiction of a decaying church, with shotguns and a ripped drum, mingled and dropped on the floor. Still standing undestroyed, an altar with a crucified Christ allures to the romantic idea of a nation that carries a predestinated mission which must triumph over all vicissitudes.

In conclusion, a broader analysis of the work of António Teixeira Lopes, as well as the knowledge of his method and art views, reveals a sculptor who, inserted in the artistic time in which he lived, grounds his work on a classical matrix (that he considered to be the backbone of sculpture) and interprets the motive with a romantic sensitivity which went on to transcend the 19th century. By challenging the naturalist label of the artist who is considered its major representative, the existence of naturalism in sculpture itself calls for revision. Therefore, we argue for a more comprehensive understanding of the art of the century in question, which hardly conforms to rigid compartments nor showcases disruption.

\section{References:}

ABREU, José Guilherme Pinto. A escultura no espaço público do Porto no século XX: inventário, história e perspectivas de interpretação. Tesis (Magister en Historia del Arte). Porto, Portugal, Universidad do Porto, Faculdade de Letras, 1996, $250 \mathrm{p}$.

BARKER, Emma (ed.). Art \& Visual Culture, 1600-1850. United Kingdom: The Open University, 2012.

BAUDELAIRE, Charles, "What is romanticism?". En: TAYLOR, Joshua C. (ed.), Nineteetn-century theories of art. California: University of California Press, 1987, pp. 220-240.

BERGER, Stefan. A Companion to nineteenth-Century Europe, 1789-1914. Oxford: Blackwell Publishing, 2009.

BERLIN, Isaiah. The roots of Romanticism. London: Pimlico, 2000.

CRANSTON, Maurice. The Romantic Movement. Oxford: Blackwell Publishers, 1994.

DAY, Aidan. Romanticism. Oxon: Routledge, 2012.

DUMEZ, Hervé. "Rodin, le Balzac et l'étude de cas". Le Libellio d' Aegis, 2007, vol. 3, pp. 35-39.

EISENMAN, F. Stephen et al. Nineteenth century art, a critical history. London: Thames and Hudson Ltd, 1998.

ELEB, Monique; DEBARRE, Anne. L'invention de I'habitation moderne. Paris 1880-1914, Suisse: Edition Hanzan et Archives d'Architecture Moderne, 1995.

Escritura de doação dos prédios onde nasceu e anexos onde existiu os seus atelieres, oficinas e dependências destinado ao comércio da sua profissão de escultor, 1933, Municipal Archive of Vila Nova de Gaia, Identifier: 2278, partial code: Lv. 16, fl. 87-93v, file number: F/04 /II/1 - Pt. 3.
FALCÃO, Isabel; POENÇA, José António (coord.). João Vaz, 1859-1931, Um pintor do naturalismo. Lisboa: Casa-Museu Anastácio Gonçalves, 2005.

FEBER, Michael. Romanticism, A very short introduction. Oxford: University Press, 2010.

FRANÇA, José-Augusto. A arte em Portugal no século $X I X$, vol. I e II. Lisboa: Livraria Bertrand, 1966.

HARRISON, Charles; WOOD, Paul; GAIGER, Jason. Art in Theory, 1815-1900, An Anthology of Changing Ideas. Oxford: Blackwell Publishing, 1998.

Inventário da Escritura de doação dos prédios onde nasceu e anexos onde existiu os seus atelieres, oficinas e dependências destinado ao comércio da sua profissão de escultor, Casa-Museu António Teixeira Lopes (House Museum of Teixeira Lopes).

LAPA, Pedro; SILVEIRA, Maria de Aires (coord.). A Arte Portuguesa do Século XIX (1859-1910). Lisboa: Museu Nacional de Arte Contemporânea - Museu do Chiado e Leya, 2010.

LOPES, António Teixeira. Ao correr da pena. Memórias de uma vida... Gaia: Câmara Municipal de Vila Nova de Gaia, 1968.

LOWY, Michael; SAYRE, Robert. Romanticism and Against the Tide of Modernity. London: Duke University Press, 2001.

LUKACHER, Brian. "Nature historicized: Constable, Turner and romantic landscape painting". En: EISENMAN, F. Stephen et al. Nineteenth century art, a critical history. London: Thames and Hudson Ltd, 1998, pp. 115-143.

MÂNTUA, Ana Anjos; SILVEIRA, Maria de Aires (ed.). Fórmulas Naturalistas da Arte Moderna nas coleções da Casa-Museu Dr. Anastácio Gonçalves e no Museu Nacional de Arte Contemporânea-Museu do Chiado. Lisboa: Direção Geral do Património Cultural, 2016.

NOVOTNY, Fritz. Painting and sculpture in Europe, 17801880. United Kingdom: The Pelican History of Art, 1960.

PEREIRA, José Fernandes. "Teoria da escultura portuguesa: 1874 - ao fim do século". Arte teoria, 2000, $n^{\circ} 9$, pp. 288-314.

PEREIRA, Paulo (dir.). História da Arte Portuguesa. Lisboa: Círculo de Leitores, 2008.

PORFIRIO, José Luís. "Da expressão romântica à estética naturalista: pintura e escultura". En: RODRIGUES, Dalila (coord.). Arte Portuguesa da Pré-História ao Século XX. Lisboa: Fubu Editores, 2009, pp. 8-97.

RODRIGUES, Dalila (coord.). Arte Portuguesa da PréHistória ao Século XX. Lisboa: Fubu Editores, 2009.

SILVA, Raquel Henriques da. "O naturalismo e o portuguesismo em pintura". En: FALCÃO, Isabel; POENÇA, José António (coord.). João Vaz, 1859-1931, Um pintor do naturalismo. Lisboa: Casa-Museu Anastácio Gonçalves, 2005, pp. 16-26.

SILVA, Raquel Henriques da. "Romantismo e pré-naturalismo". En: PEREIRA, Paulo (dir.). História da Arte Portuguesa. Lisboa: Círculo de Leitores, 2008, pp. 155-193.

SILVA, Raquel Henriques da. "Silva Porto e a pintura naturalista". En: LAPA, Pedro; SILVEIRA, Maria de Aires (coord.). A Arte Portuguesa do Século XIX (1859-1910). Lisboa: Museu Nacional de Arte Contemporânea Museu do Chiado e Leya, 2010, pp. 51-63.

TAYLOR, Joshua C. (ed.). Nineteetn-century theories of art. California: University of California Press, 1987.

VAUGHAN, William. Romanticism and art. Londres: Thames \& Hudson Ltd, 2003.

WU, Ducan. A Companion to Romanticism. Oxford: Blackwell Publishing, 1999. 